\title{
Bimbingan Kelompok Pranikah Dalam Mencegah Perceraian Pada Calon Pengantin
}

\author{
Rita anriani ${ }^{1}$, Nurjannah ${ }^{2}$ \\ ${ }^{1}$ Universitas Islam Negeri Sunan Kalijaga Yogyakarta \\ ${ }^{2}$ Universitas Islam Negeri Sunan Kalijaga Yogyakarta
}

\section{Article Info \\ Article history: \\ Received Jun $12^{\text {th }}, 2021$ \\ Revised Aug 20 $0^{\text {th }}, 2021$ \\ Accepted Oct $26^{\text {th }}, 2021$}

\section{Keyword:}

Divorce, Group Guidance, Marriage

\begin{abstract}
ABSTRAK
Setiap manusia diciptakan berpasang-pasangan dengan ikatan pernikahan dan setiap orang ingin memiliki keluarga yang harmonis. Banyak pasangan di Kota Dumai yang tidak memiliki keluarga yang harmonis membuat mereka memilih untuk bercerai. Penyebab pasangan bercerai di Kota Dumai antara lain mandat, meninggalkan salah satu, masuk penjara, KDRT, perselisihan dan pertengkaran, ekonomi, poligami, kawin paksa, cacat fisik, judi, dan murtad. Oleh karena itu diperlukan pembekalan dan pemahaman dalam menghadapi kehidupan rumah tangga bagi calon pengantin yaitu dengan program bimbingan pranikah bagi calon penganten untuk mempersiapkan pasangan dalam menghadapi rumah tangga. Tujuan penelitian ini yaitu bagaimana bimbingan kelompok pranikah dalam mencegah percerain pada calon penganten di KUA Kecematan Dumai Timur. Penelitian ini menggunakan deskriptif kualitatif, subjek dalam penelitian ini yaitu calon penganten. Adapun hasil penelitian ini, bimbingan kelompok pranikah sangat efektif dalam menyiapkan calon penganten dalam menghadapi rumah tangga. Adapun tahap-tahap yang digunakan dalam bimbingan pranikah di KUA Kecematan Dumai Timur yaitu: tahap pembentukan, tahap peralihan, tahap kegiatan, dan tahap pengakhiran.
\end{abstract}

\begin{abstract}
The increasing number of divorce cases in society lately has caused concern for prospective brides, considering that the family is one of the best places for each individual to build life. Every divorced couple will have a negative impact on the economy, social and culture of the couple, especially for those couples who have children. Children are one of the victims of divorced couples. Therefore, it is necessary to provide briefing and procedures for dealing with domestic life for the bride and groom, namely the marriage guidance program for the prospective bride and groom to prepare the couple to face the household. The purpose of this study is how to guide premarital groups in preventing divorce for prospective brides at the KUA Kecematan Dumai Timur. This study uses a qualitative descriptive, the subject in this study is the prospective bride. As for the results of this study, premarital group guidance is very effective in preparing prospective brides to face the household. The stages used in pre-marital guidance at the East Dumai District KUA are: the formation stage, the transition stage, the activity stage, and the termination stage..
\end{abstract}

(C) 2021 The Authors. Published by UIN Sultan Syarif Kasim Riau.

This is an open access article under the CC BY license

(https://creativecommons.org/licenses/by/4.0) 


\section{Corresponding Author:}

Rita Anriani,

Univeristas Islam Negeri Sunan Kalijaga Yogyakarta

Email: Ritaanriani40@gmail.com

\section{PENDAHULUAN}

Setiap manusia di ciptakan berpasang-pasangan yang diikat dalam sebuah pernikahan. Pernikahan adalah keinginan semua orang karena pernikahan merupakan salah satu cara mendapatkan kasih sayang dari ketenangan jiwa dan kasih sayang dari pasangan. Pernikahan merupakan perbuatan yang mulia bersifat abadi dan bukan untuk waktu yang singkat, oleh karena itu harus dijalinkan dengan ikatan lahir dan batin pada pasangan. Pernikahan dalam hukum islam merupakan ibadah terpanjang dalam mentaati perintah Allah SWT. Pernikahan bukan hanya menyatukan dua insan antara laki-laki dan perempuan saja tapi juga untuk memenuhi perintah Allah SWT baik dalam kebutuhan dunia maupun kebutuhan akhirat (Zatrahadi, 2016).

Pernikahan merupakan ikatan lahir dan batin yang sifatnya agung dan suci antara pasangan laki-laki dan perempuan, yang bertujuan untuk membuat pasangan suami istri merasa dalam ketenangan, ketentraman, aman dan damai (sakinah), merasakan kasih sayang dan cinta yang tulus terhadap pasangan (mawaddah), dan untuk mendapatkan karunia dari Allah SWT berupa ampunan, rahmat dan rezeki yang tidak terhingga di dalam rumah tangga (warahmah) (Zatrahadi, 2016). Dalam membentuk rumah tangga seperti itu yang sakinah, mawaddah, dan warahmah adalah keinginan semua pasangan suami istri. Namun, untuk mencapai keluarga SAMARA diperlukan persiapan yang matang, persiapan fisik, mental, ilmu dalam berumah tangga, kesiapan menghadapi problem dan cara mengatasinya agar apa yang tidak diinginkan terjadi yaitu percerain (Devianti \& Rahima, 2021).

Jika di dalam rumah tangga tidak tercapai keluarga yang SAMARA maka akan menyebabkan perselisihan dan konflik anar suami istri yang bisa menyebabkan percerain. Dimana perceraian merupakan hal yang dibenci oleh Allah SWT, tapi boleh dilakukan. Karena percerain akan memunculkan permasalah terhadap suami istri dan keluarga sehingga membuat masing-masing menjalinkan kehidupan kesehariannya jadi efektif tapi bisa juga tidak efektif malah mungkin bisa hancur. Perceraian yang terjadi bisa menyebabkan permasalahan berupa gangguan kepribadian seperti depresi, stres dan lainya, juga menyebabkan munculnya masalah ekonomi dan sosial setelah terjadinya prcerain (Taufik, 2015).

Percerain menurut Kitab Undang-Undang Hukum (KUH) pada pasal 113, penyebab putushnya pernikahan atau percerain antara suami isteri disebabkan, kematian, percerain, dan putusan pengadilan. Percerain yang terjadi karena dua hal yaitu suami menjatuhkan talak terhadap istri dan istri menggugat suaminya. Penyebab perceraian itu bermacam-macam dari yang salah satu pasangan selingkuh, adanya KDRT baik fisik maupun psikis, meninggalkan salah satu pasangan, di penjara, mengalami cacat fisik, dan perselisihan suami istri (Zatrahadi, 2016).

Hal ini bermakna bahwa Islam benar-benar mengharapkan setiap manusia muslim harus serius dalam urusan pernikahan. Agar manusia mencapai keluarga yang SAMARA. Oleh karena itu diperlukan pembekalan dan tata cara dalam menghadapi kehidupan rumah tangga bagi calon pegantin yaitu dengan program bimbingan perkawinan bagi calon penganten yang biasa di sebut dengan konseling pranikah. bimbingan pranikah merupakan kegiatan penting untuk mempersiapkan pasangan dalam menghadapi rumah tangga. Sehingga memungkinkan semakin kecil resiko perceraian (Taufik, 2015).

Dalam program tersebut pemerintah melalui kementrian agama yang dilaksanakan di Kantor Urusan Agama (KUA) maka dalam melaksanakan bimbingan pranikah melalui badan yang telah ditunjuk dan berwenang yakni Badan Penasehat dan Pelestarain Perkawinan (BP4), dimana dalam Kepdirjend Nomor 373 Tahun 2017 menerbitkan tentang petunjuk teknis bimbingan perkawinan pranikah (Dirjen Bimas Islam, 2017). Begitu juga pada KUA Kecamatan Dumai Timur selalu melaksanakan Bimbingan Perkawinan bagi calon-calon pengantin yang akan menikah. Calon-calon pengantin tersebut diberi pembekalan dalam menghadapi kehidupan rumah tangga sehingga terhindar dari percerain. Dalam penelitian Ahmad pada tahun 2019, terdapat beberapa hal melatarbelakangi pentingnya bimbingan dan konseling perkawinan, yaitu: permasalahan individu, manusia makhluk sosial yaitu membutuhkan orang lain dalam kehidupan, masalah ekonomi, adat dan budaya yang bermacam-macam (Miftahudin, 2019).

Dalam penelitian rika dan raja pada tahun 2021, Pelaksanaan layanan bimbingan konseling pranikah dapat dilaksanakan dengan beberapa layanan, seperti layanan informasi, layanan konsultasi, layanan konseling kelompok, dan konseling individual. Pelaksanaan layanan tersebut dapat dilakukan dengan beberapa cara baik secara langsung (tatap muka) maupun secara tidak langsung (menggunakan media masa) (Devianti \& Rahima, 2021). Di KUA Kecamatan Dumai Timur bimbingan pranikah dilaksanakan melalui layanan bimbingan kelompok yang dilakukan secara langsung. 


\section{METODE}

Penelitian ini menggunakan deskriptif kualitatif, yaitu menggambarkan atau menjelaskan secara sistematis. Sedangkan pendekatan penelitain yang digunakan ialah pendekatan kualitatif, yaitu menggambarkan, meringkas berbagai kondisi dan situasi dengan fenomena sosial yang ada dimasyarakat yang menjadi objek penelitian (Sugiono, 2013). Sumber data yang diperoleh primer yaitu sumber data yang diperoleh dan di kumpulkan langsung dari lapangan, subjek penelitian ini dua pasang calon penganten. Dan teknik pengumpulan data menggunakan studi lapangan yang dilakukan dengan cara turun langsung ke lapangan dengan menggunakan intrumen penelitian yaitu, observasi, wawancara dan dokumentasi.

\section{PEMBAHASAN}

Penyebab Percerain

Didalam hasil Penelitian Taufik pada tahun 2015 ada beberapa penyebab percerain yaitu, poligami, krisis akhlak, cemburu, ekonomi, tidak bertanggung jawab, dihukum/dipenjara, gangguan dari pihak ketiga, tidak adanya keharmonisan dan cacat biologis. Dari beberapa penyebab perceraian tersebut yang paling banyak kasusnya ada pada tidak bertanggung jawab baik pihak suami maupun pihak istri. Setiap pasangan suami istri harus mempunyai komitmen-komitmen di dalam rumah tangga. Komitmen tersebut sebaiknya ditata sebelum pernikahan sehingga ketika sudah berumah tangga tinggal merealisasikan saja lagi agar terbentuk perkawinan yang sakinah, mawaddah dan warahma. Adapun komitmen-komitmen yang harus dipenuhi dalam rumah tangga yaitu komitmen personal, komitmen moral, dan komitmen struktural (Taufik, 2015).

Untuk mempertahankan keutuhan rumah tangga agar terhindar dari perceraian ada beberapa aspek ketahanan keluarga, yaitu 1) ketahanan fisik yaitu memenuhi kebutuhan sandang (pakain), pangan (makan dan minum yang halal), papan (rumah). 2) ketahan non fisik yaitu memenuhi kebutuhan rohani dan psikis untuk pasangan dan anak-anak sehingga merasa aman, nyaman penuh cinta kasih dan damai di dalam rumah. 3) ketahanan sosial yaitu memenuhi fungsi keluarga baik suami, istri dan anak-anak dan menjalinkan hubungan yang baik di lingkungan. 4) ketahan dibidang agama dan hukum yaitu membina keluarga berdasarkan agama dan menjalankan tanggung jawab dan hak masing-masing antar keluarga yaitu suami dan istri, orang tua, dan anak-anak (Zatrahadi, 2016).

Percerain menurut Kitab Undang-Undang Hukum (KUH) pada pasal 113, penyebab putushnya pernikahan atau percerain antara suami isteri disebabkan, kematian, percerain, dan putusan pengadilan. Percerain yang terjadi karena dua hal yaitu suami menjatuhkan talak terhadap istri dan istri menggugat suaminya. Penyebab perceraian itu bermacam-macam dari yang salah satu pasangan selingkuh, adanya KDRT baik fisik maupun psikis, meninggalkan salah satu pasangan, di penjara, mengalami cacat fisik, dan perselisihan suami istri (Zatrahadi, 2016).

Begitu pula yang terjadi pada Pengadilan Agama Dumai Kelas II B, banyak berbagai permasalahan yang terjadi di pasangan suami istri yang menyebabkan perceraian yang dapat diliat pada tabel 1 .

Tabel 1

(Kasus Percerain Di Pengadilan Agama Dumai Kelas II B Dari Tahun 2018-2020)

\begin{tabular}{clccc}
\hline No. & \multicolumn{1}{c}{ Penyebab Percerain } & $\mathbf{2 0 1 8}$ & $\mathbf{2 0 1 9}$ & $\mathbf{2 0 2 0}$ \\
\hline 1. & Mandat & 2 & - & 2 \\
2. & Meninggalkan salah satu & 59 & 107 & 48 \\
3. & Masuk Penjara & 8 & 24 & 4 \\
4. & KDRT & 6 & - & 1 \\
5. & Perselisihan dan Pertengkaran & 258 & 348 & 238 \\
6. & Ekonomi & 14 & 22 & 3 \\
7. & Poligami & 1 & - & - \\
8. & Kawin paksa & 11 & - & - \\
9. & Cacat fisik & 19 & - & - \\
10. & Judi & 3 & - & - \\
11. & Murtad & 3 & - & - \\
& & 384 & 493 & 296 \\
\hline
\end{tabular}

Sumber: Laporan tahunan pengalilan agama Dumai kelas II B

Dari tabel di atas dapat di lihat bahwa tiga tahun terakhir di Pengadilan Agama Dumai Kelas II B penyebab perceraian yang paling tinggi karena perselisihan dan pertengkaran pasangan suami istri. Perselisihan dan pertengkaran suami istri biasa terjadi pada pasangan tapi perselisihan dan pertengkaran tersebut terjadi terus menerus dan dibiarkan tanpa menyelesaian menyebabkan perceraian. Pasangan suami istri masih banyak belum saling memahami keadaan pasangan masing-masig baik dari sosial dan psikologisnya sehingga terjadi 
perselisihan dan pertengkaran terus menerus. Penyebab perceraian setelah perselisihan dan pertengkaran adalah meninggalkan salah satu pasangan.

\section{Bimbingan Kolompok Pranikah}

Pelaksanaan layanan bimbingan konseling pranikah dapat dilaksanakan dengan beberapa layanan, seperti layanan informasi, layanan konsultasi, layanan konseling kelompok, dan konseling individual. Pelaksanaan layanan tersebut dapat dilakukan dengan beberapa cara baik secara langsung (tatap muka) maupun secara tidak langsung (menggunakan media masa (Devianti \& Rahima, 2021). Pelaksana layanang bimbingan konseling bis gunakan apa saja sesua dengan kebutuhan yang ada pada lapangan. Di KUA Dumai Timur pelaksanaan bimbingan konseling melalui lembaga BP4 melakuan layanana bimbingan konseling dengan menggunakan layanan bimbingan konseling kelompok. Karena layanan yaang di berikan kepada calon penganten seminggu sekali yaitu setiap hari selasa dari pukul 08.00-12.00 WIB yang biasanya di ikuti oleh dua hingga tujuh pasang calon penganteng. Layanan tersebut diberikan kepada calon penganten seminggu sebelum nikah.

Layanan kelompok juga memiliki banyak kengugulannya seperti belajar memahami tingkah laku yang sudah ada dan memahami tingkah laku yang baru. Menurut Brown kelompok merupakan sarana bagi anggota kelompok untuk memahami dan mengetahui informasi-informasi diri sendiri dan tingkah laku anggota lainnya, kelompok juga untuk belajar mengendalikan diri dan mengubah diri menjadi lebuh baik lagi (dalam Taufik, 2015). Setiap individu membutuhkan orang lain baik dalam keadaan susah maupun senang. Oleh karena itu individu membentuk kelompok-kelompok yang bisa berupa kelompok budaya, pertemanan, pekerjaan dan banyak laiannya. Dimana kelompok berguna meningkatkan hubungan individu dengan orang lain berupa memberi dan menerima, berkomunikasi serta berguna untuk menampilkan emosi dan keadaan apa adanya.

Begitu juga dengan bimbingan kelompok yang merupakan salah satu layanan bimbingan konseling. Corey berpendapat bimbingan kelompok lebih berkesan dari pada bimbingan individu, di karenakan anggota kelompok saling belajar dan memahami dari anggota lainnya sehingga menambah informasi dan membuka pemikiran baru (Taufik, 2015). Bimbingan kelompok memiliki beberapa kelebihan yaitu. Pertama, anggota dapat beinteraksi dengan konselor dan anggota lain. Dengan bimbingan kelompok pranikah ini yang awal tidak saling kenal antara pasangan satu dengan pasangan lainya jadi kenal dan malah lebih kenal karena saling berinteraksi sehingga para calon penganten saling memberikan pendapat, tanggapan dan saran. Dimana pemimpin kelompok (konselor) memberikan informasi-informasi tentang pernikahan terlebih dahulu sebelum para calon penganten memberikan pendapat, tanggapan dan saran.Kedua dengan bimbingan kelompok menimpulkan saling percaya karena dalam proses bimbingan kelompok belajar saling memahami antara pasangan dan anggota lainnya. Dari sifat saling percaya tersebut para anggota mengeluarkan isi hatinya kepada pasangan masing-masing. Ketiga dalam bimbingan kelompok para calon pengantin dilatih mengkondisikan pikiran dan perasaannya dalam berkomunikasi sehingga secara tidak langung para calon penganten mampu berkomunikasi dengan baik selama bimbingan pranikah. Keempat dalam bimbingan kelompok calon penganten dilatih untuk mampu memecahkan konflik rumah tangga nantinya dengan menjaga komunikasi antara pasangan. (dalam Erlangga, 2017).

Bimbingan pranikah yang diberikan kepada calon penganten bertujuan untuk membentuk dan membangun kekuatan rumah tangga sehingga terbentuk keluarga sakinah, mawaddah, dan warahmah. Adapun kekuatan tersebut terbuntuk jika dari awal pernikahan memiliki komitmen, waktu yang menyenangkan, menhindari serta memecahkan permasalahan, komunikasi yang baik, memiliki kesehatan spiritual dan memiliki kasih sayang antara pasangan (Taufik, 2015). Menurut Danuri untuk mewujudkan keluarga yang harmonis ada beberapa hal yang harus di miliki dalam keluarga, yaitu: ketenangan jiwa yang didasari oleh beriman kepada Tuhan Yang Maha Esa, memiliki hubungan yang baik atar keluraga dan masyarakat, kesehatan jasmani dan rohani terjaga, terpenuhi kebutuhan sandang, pangan, dan papan, adanya hak asasi manusia, adanya pendidikan, dan ada jaminan masa tua (dalam Noffiyanti, 2020).

Bimbingan kelompok membutuhkan interaksi yang baik sehingga terjalin komunikasi yang baik juga di dalam proses bimbingan pranikah. Menurut Kumar komunikasi antar pribadi berupa keterbuakaan, empati, saling percaya, saling mendukung dan menyamaratakan anggota kelompok tanpa membeda-bedakannya sangatlah penting dalam bimbingan kelompok. Bimbingan kelompok pranikah ini diharapkan dapat memunculkan interaksi yang baik, dapat memahami dan menjalinkan rumah tangga dengan baik sehingga terhindar dari percerain (Erlangga, 2017).

\section{Pelaksanaan Bimbingan Kolompok Pranikah Pada Calon Penganten}

Pelaksanaan bimbingan kelompok pada tanggal 21 Oktober 2021 di KUA Dumai Timur yang dilaksanakan Pukul 08.00-12.00 WIB. Waktu pelaksanaan bimbingan pranikah di kurangi dari pada waktu biasanya karena keadaan pandemi yang sedang dihadapi mengharuskan mengurangi aktifitas di luar rumah dan berkerumun sehingga waktu bimbingan pranikah di kurangi agar terhindar dari terpaparnya virus Covid- 
19. Pelaksanaan Bimbingan kelompok ini di pimpin oleh Bpk Surya Hudaya, S.Ag selaku penghulu dan saya sebagai peneliti deberi kesempatan kurang lebih 1 jam dalam proses bimbingan kelompok pranikah.

Setiap bimbingan pasti memiliki tahap-tahap pelaksanaan agar layanan yang diberikan berjalan lancar dan mencapai tujuan. Oleh karena itu layanan bimbingan kelompok pranikah menggunakan empat tahap diamana menurut Prayitno pelaksanaan bimbingan kelompok menggunakan empat tahap, yaitu: tahap pembentukan, tahap peralihan, tahap kegiatan, dan tahap pengakhiran (Prayetno, 2005).

Tahap pertama, pembentukan. Pada tahap ini KUA Dumai Timur melakukan pembentukan kelompok terlebih dahulu sesuai dengan jadwal ijab kabul calon penganten. Kelompok terdiri Dari dua pasang calon penganten, yang akan melaksanakan pernikahan tanggal 23 dan 24 Oktober 2021. Pada tahap ini juga merupakan tahap perkenalan, dimulai dari konselor akan memperkenalkan diri dan menjelaskan pengertian, tujuan dan manfaat pelaksanaan bimbingan kelompok pranikah. Dan sebaliknya para calon penganten memperkenalkan diri dan juga saling mengungkapkan tujuan dan harapanya dalam mengikuti bimbingan kelompok pranikah.

Tahap kedua, peralihan. Pada tahap ini konselor menyampaikan kepada para calon penganten bahwa kegiatan ini mendiskusikan suatu topik yang berkaitan dengan para anggota yaitu tentang pernikahan dan kehidupan setelah menikah. Dalam tahap peralihan ini juga mempersiapkan peralihan dari tahap pembentukan ketahap diskusi kelompok. Tahap ini berguna menyiapkan anggota kelompok agar bersungguh-sungguh melaksanakan layanan ini agar mampu mendalami topik yang akan dibahas.

Tahap ketiga, kegiatan. Tahap ini adalah inti dari tahap-tahap yang ada dimana pada tahap ini konselor akan menyampaikan materi tentang kehidupan pernikahan dimana calon penganten harus memahami kehidupan pernikahan sebelum menjalinkan kehidupan rumah tangga dan terhindar dari hal yang tidak di inginkan seperti perceraian. Adapun materi yang di berikan konselor kepada para calon penganten yaitu (Riyadi, 2019):

a. Pernikahan

Dalam Undang-Undang RI No.1 Tahun mengatakan pernikahan merupakan ikatan lahir batin dua insan yaitu seorang laki-laki dan perempuan yang menjadi suami istri dengan membentuk rumah tangga yang bahagia berdasarkan Tuhan Yang Maha Esa. Memberikan bimbingan kepada calon penganten untuk membentuk rumah tangga yang aman, nyaman dan bahagia yang di dasarkan oleh mendekati diri dengan Tuhan Yang Maha Esa (Al Farisi, 2022).

b. Fisiologis (fisik)

Memahami dan mengetahui kesehatan calon masing-masing disarankan untuk meriksa kesehatan kesehatan kedokter. Agar ketika ada kelemahan atau permasalahan bisa di atasi bersama untuk mengatasi sedini mungkin. Dan salah satu tujuan pernikahan ialah ingin memiliki keturunan. Untuk memiliki keturunan yang yang sehat, pasangan suami istri juga harus memiliki keadaan yang sehat juga (Zatrahadi, 2016). Di KUA Kecamatan Dumai timur juga melakukan pemberian materi dan cek kesehatan fisik yang dilakukan oleh orang kesehatan dari puskesmas Dumai Timur.

c. Psikologis (mental)

Memahami dan mengetahui kedaan psikis calon pasangan masing-masing dengan mematangkan emosi dan pikiran, menerima satu sama lain sifat dan karakter pasangan, saling perngertian dalam menjalinkan pernikahan dan memberikan cinta kasih yang tulus.

d. Psikososial dan Spiritual

1) Beragama dan berakhlak mulia

Setiap manusia sudah memiliki agama sejak lahir yang di turunkan dari orang tuanya dan didik menjadi pribadi yang berakhlak mulia sehingga manusia mampu memahami keagamanan yang baik untuk dirinya dan orang sekelilingnya. Ketika manusia melangkah untuk mendirikan rumah tangga maka mereka harus memiliki ilmu agama dan memiliki akhlak yang baik. Karena agama dan akhlak mulia akan membantu pasanga suami istri dalam membangun dan mempertahankan rumah tangga nantinya yang membentuk keluarga sakinah, mawaddah, dan warahmah.

2) Nasab (keturunan)

Setiap pasangan yang menikah salah satu keinginan mereka dalam berumah tangga yaitu memiliki keturuanan yang baik. Untuk mendapatkan keturunan yang baik maka pasangan yang akan dinikahi dari keturunan yang baik juga. Pada umumnya seseorang yang lahir dalam keturunan yang baik akan terhindar dari kehinaan, kerendahan, dan penyimpangan. Oleh karena itu ketika seseorang untuk memilih menikah dan memilih pasangan hidup diperlukan untuk mengetahui bagaimana keturunan calon pasangannya sehingga terhindar dari perbuatan-perbuatan yang tidak baik dan menyimpang nantinya

3) Pergaulan

Sebelum rencanakan pernikahan, pasangan harus saling mengenal satu sama lain. Memahami pergaulan keseharian calon pasangan masing-masing yang sesuai dengan etika dan kaidah agama. 
Dan ketika sudah berumah tangga pergaulan suami istri lebih dibatasi lagi agar terhindar dari bahaya dan fitnah nantinya (Zatrahadi, 2016).

4) Persipan material

Untuk membangun rumah tangga calon pasangan suami istri harus memahami tanggu jawab mereka nantinya salah satunya yaitu tanggu jawab suami dalam memenuhi nafkah lahir yang berupa materi dan istri dalam mengelola keuangan rumah tangga. Untuk itu calon suami dan istri mempersiapkan hal-hal tersebut sehingga ketika berumah tangga menjalinkannya lagi (Zatrahadi, 2016).

e. Konflik Keluarga

Konflik untuk menguji bagaimana karakteristik suatu hubungan antarpribadi (Sri Lestari, 2013: 102). Ketika laki-laki dan perempun disatukan dalam rumah tangga yaitu pasangan suami istri akan ada perselisihan dan salah paham nantinya. Oleh karena itu suatu pernikahan pasangan suami istri harus saling memahami dan memiliki hubungan yang berkualitas agar mampu memahami situasi dan mengontrol apa yang terjadi nantinya baik itu konflik di dalam rumah tangga. Konflik akan memungkinnya munculnya emosi yang negatif baik berupa marah, jengkel, sakit hati, tidak percaya dengan pasangan, dan komunikasi tidak berjalan baik. Untuk memahami dan mengontrol hal tersebut pasangan suami istri memiliki stategi dalam menangani setiap permasalahan yang akan datang. Karena setaip permasalahan dan konflik yang terjadi di rumah tangga akan memperkuat hubungan suami istri tergantung gimana pasangan masingmasing mengatasinya (Zatrahadi, 2016).

Materi-materi yang dibahas sesuai dengan kebutuhan-kebutuhan dalam pernikahan dan juga sesuai dengan kewenangan kementrian agama RI. Di dalam proses bimbingan kelompok pranikah ini konselor memberikan materi pertopik. Setelah memberikan topik pertama konselor memberikan kesempatan kepada calon penganten untuk mendeskripsikan, bertanya dan mendiskusikannya bersamasama sehingga calon penganten memiliki pemikiran baru tentang pernikahan. Konselor juga memberikan kebebbasan kepada para calon penganten untuk memberikan pendapatnya secara leluasa dengan adil. Setelah membahas topik pertama di lanjutkan kepada topik selanjutnya dengan proses yang sama dan sampai topik yang dibahas selesai. Akhir dari tahap ini konselor meminta masing-masing pasangan untuk menyikapin dan melaksanakan apa yang sudah dipelajari agar terhindar dari yang tdiak dinginkan yaitu percerain.

Pada tahap keempat, pada tahap ini adalah tahap pengakhiran yang biasanya disebut dengan tahap evalusi. Pada tahap ini konselor memberikan kesempatan kepada anggota atas kesan dan pesan terhap layanan bimbingan konsempok pra-nikah ini. Pada tahap para pasangan memberikan pesan dan kesannya, pada pasangan pertama berpendapat bahwa bimbingan kelompok pranikah ini sangat membantu mereka, menabahkan pengetahuan yang belum mereka tau tentang pernikahan dan menurut mereka bimbingan konseling ini sangat efektif dalam mengurangi kasus perceraain dengan lebih memahami pasangan dan keadaan sekitar. Pada pasangan kedua berpendapat yang sama dengan pasangan pertama dan mereka juga menyarankan ditambahkan waktunya bimbingan karena waktu yang diberikan cukup singkat dalam mempelajari hidup pernikahan.

\section{SIMPULAN}

Pernikahan merupakan ikatan lahir dan batin yang sifatnya agung dan suci antara pasangan laki-laki dan perempuan, yang bertujuan mencapai kelurga sakinah, mawaddah, dan warahmah. Oleh karena itu dibutuhkanlah bimbingan pranikah ini bagi calon penganten dalam mempersiapkan kehidupannya dalam mengadap hirup pikuk rumah tangga sehingga mereka mampun membentuk keluraga yang SAMARA. Semakin siap mereka menghadapin kehidupan rumah tangga maka semakin kecil pula resiko percerain. Proses bimbingan melalui bimbingan kelompok oleh para penghulu di Kantor Urusan Agama (KUA). Dimana bimbingan kelompok ini sangat efektif dan membuat pasangan saling belajar dengan pasangan lain. Layanan bimbingan kelompok yang diselenggarakan oleh BP4 di KUA Dumai Timur sesuia dengan petunjuk teknis bimbingan perkawinan pranikah di Kepdirjend Nomor 373 Tahun 2017. Materi yang dibahas menyangkut tentang aspek pernikahan, fisiologis, psikologis, psikososial dan sosial, dan konflik keluarga.

\section{Referensi}

Al Farisi, S. (2021). Peran Bimbingan Pranikah Dalam Keharmonisan Keluarga (Studi Kasus di KUA Dau Kabupaten Malang). Turatsuna: Jurnal Keislaman dan Pendidikan, 4(1), 45-60.

Devianti, R., \& Rahima, R. (2021). Konseling Pra-Nikah menuju Keluarga Samara. Educational Guidance and Counseling Development Journal, 4(2), 73-79. http://ejournal.uinsuska.ac.id/index.php/EGCDJ/article/view/14572 
Dirjen Bimas Islam. (2017). Kepdirjen Bimas Islam nomor 373 tahun 2017 (p. 373). https://simbi.kemenag.go.id/epustaka_slims/index.php?p=show_detail\&id=21\&keywords=

Erlangga, E. (2017). Bimbingan Kelompok Meningkatkan Keterampilan Berkomunikasi Siswa. Psympathic: Jurnal Ilmiah Psikologi, 4(1), 149-156. https://doi.org/10.15575/psy.v4i1.1332

Noffiyanti. (2020). Mewujudkan Keharmonisan Rumah Tangga dengan Menggunakan Konseling Keluarga. Al-Ittizaan: Jurnal Bimbingan Konseling Islam, 3(1), 8-12.

Miftahudin, Ahmad (2019). Efektivitas Bimbingan Konseling Pranikah. Turatsuna: Jurnal Keislaman dan Pendidikan, 21(1), 107-118.

Pengadilan Agama Dumai Kelas II. (2021). Laporan Tahunan Tahun 2018-2020. Tidak diterbitkan.

Prayitno. (2005). Layanan Bimbingan dan Konseling Kelompok (Dasar dan Profil) Jakarta: Ghalia Indonesia

Riyadi, D. S. (2019). Psychological Analysis of the Upgrading Premarital Material Analisis Psikologi Terhadap Materi Penataran Pranikah. 521-566.

Sugiyono (2013) .Metode Penelitian Manajemen. Bandung: CV Alfabeta

Taufik. (2015). Bimbingan Kelompok Pra-Nikah Bagi Mencegah Perceraian di Kalangan Pasangan Muda. Jurnal Ilmiah Ilmu Pendidikan, 15(2), 118-124.

Zatrahadi, M.Fahli (2016). Pengantar Konseling Perkawinan. Pekanbaru: Riau Creative Multimedia 